\title{
Textural Properties of Rock for Penetration RATE PREDICTION
}

\author{
B. Adebayo ${ }^{1}$ and J.M. Akande ${ }^{2}$ \\ Department of Mining Engineering, Federal University of Technology, \\ Akure, NIGERIA. \\ E-mail: 'baayoakinola@yahoo.com and 2akandejn@yahoo.com
}

\begin{abstract}
The relationship between textural properties of selected Nigeria rocks and penetration rate of top-hole hammer drill was investigated. These rock samples were tested in the laboratory for mineral composition, silica content and porosity. Also, average grain size and packing density were determined from photomicrograph of the samples using empirical equations proposed by researchers. Penetration rate for each rock samples obtained in the field were correlated with the textural properties to establish their relationships. The results show that all textural character and penetration rate have high coefficient of correlation for all the samples. The highest penetration rate was experience on biotite hornblende-granite having mean packing density of $92.58 \%$ and the silica content vary for $82.60-82.72 \%$. This has revealed that penetration rate of rock drill bit in quarries is related to textural rock properties and this will be necessary to have overview of time of drilling as well as rock response to mechanical loading.
\end{abstract}

Keywords: Textural properties, rocks, packing density, penetration rate, top-hole-hammer drill and quarry

\section{Introduction}

Investigations of nature, characteristics as well as properties of rock are essential for determination of response of rock mass to mechanical fragmentation in quarries and mines. Also, rock engineers are eager to know or make projection before and during exploitation of particular rock type. Bilgin et al.,[1] opined that the ability of excavation machines to operate and cut effectively in hard rock is limited by system stiffness and the ability to of the cutting tool to withstand high forces. The variation in the resistance experience on different rock types depend on the textural character and mineralogical composition of the rocks. However, considering design of mechanical equipment for drilling operation, excavation, hauling and crushing rely to a large extent on quality and quantity of textural characteristics data available. This will help mine manager in selection of appropriate machinery for their different levels of operation and guarantee optimum performance of the equipment.

William et al.,[2] define rock texture as the degree of crystallinity, grain size or granularity and fabric or geometrical relationship between the constituent of a rock. Erosy and Waller [3] explained that textural characteristics refer to the geometrical features of rock particles such as grain size, grain shape, grain orientation, relative areas of the grain and matrix (packing density) and compositional features such as mineral content, cement type, degree of cementation or crystallization and bond structure and concluded that textural character are major factor in determining the mechanical behaviour of rocks which can be used as a predictive factor for assessing the drillability, mechanical and wear performance of rocks. In addition Ulusay et al.,[4] described all these properties as petrographic characteristics affecting the behaviour of rock and can be readily measured in the laboratory and determined during routine thin-section studies. Also, Tug rul and Zarif [5] confirmed that the physical and mechanical behaviour are a function of mineralogical and textural character of the rock.

It had been examined that grain boundary or contact relationship are complex [6]. In the study of [7] the variation in penetration rate correlate with changes in the nature of rock and the variation in rotary toque having clear impact from changes in rock hardness. Some group of researchers expressed that mineral composition and fabric have a key effect on damage mechanism of rock and identified that two mechanisms throughout the loading 
process are compaction and micros-cracking [8]. Therefore, precise determination of penetration rate will assist projecting time that would be consumed in drill at certain depth of rock. This can also be explained as the rate at which the bit enters or advanced in to the rock. Beste et al.,[9] observed that rock is normally considered rather hard and offers resistance to bit penetration. The penetration mechanisms of drilling may vary in character depending on rock type. Kahraman et al.,[10] correlated penetration rate with rock properties and they discovered Schmidt hammer value has strong correlation with penetration. Penetration rate has been known as the most effective parameter in determining the boundary between different rock types [11]. This work is to study evaluate textural characteristics as well establish their relationship with penetration rate.

\section{Materials and Method \\ 2.1 Rock samples}

Feldspar granite, Biotite hornblende granite and Coarse biotite granite were used for the various test required for this work.

\subsection{Determination of mineral composition}

The thin section prepared from the rock samples were viewed under a polarizing microscope and the mineral composition of the rocks were estimated as presented in Tables 1- 3

\subsection{Determination of average grain size}

The average grain size was measured manually from the photomicrograph of the thin section. In addition, all the grains in the reference area were measured and the average of grain size was calculated for all the samples.

\section{$2.4 \mathrm{X}$ - ray fluorescence test for determination of silica content}

The palletized samples were inserted into the sample holder were prepared in accordance with [12], so that the beams of x-ray light can fall on flat surface of the palletized sample. The RIX 3100 X-Ray Spectrometer equipped with a monitor process each sample inserted and analyse the percentage of each elements present in the sample. The result is presented in Table 5

\subsection{Determination of porosity}

Porosity was determined using saturation and caliper technique as suggested by [13]. The representative sample of the rock was machined to conform to cubiod. The bulk volume $\mathrm{V}_{\mathrm{b}}$ was calculated from caliper reading for each dimension. The sample was saturated by water immersion for a period of 5 days. The sample was removed surface dried, and the saturated surface dry mass was determined. The sample was dried to a constant mass at a temperature of $105^{\circ} \mathrm{C}$, cooled in a desiccator and its mass determined to give grain mass Ms. The pore volume and porosity were obtained using equations 1 and 2 as shown in Table 6

$\mathrm{Vp}=\frac{(\text { Msat }-\mathrm{Ms}\rangle}{\rho w}$

where $\rho_{\mathrm{w}}=$ density of the saturated fluid (water)

$\mathrm{Vp}=$ pore volume

Porasity $(n)=\frac{100 \mathrm{vp}}{\mathrm{vb}_{\mathrm{b}}}$

\subsection{Determination of packing density}

The packing density for the samples were determined using equation 3 proposed by [14] and the results are presented in Table 7.

$P D=\frac{\sum \text { Length Grains along traverse }}{\text { Length of Traverse }}$

\section{Results and Discussion}

\subsection{Textural properties}

The mineral composition of feldspar granite, biotite hornblende granite and coarse biotite granite are shown in Tables 1-3. The results show that the percentage of quartz, biotite and plagioclase are $42,30.6$, and $13.1 \%$ for feldspar granite; $51.11,17.78$, and $6.66 \%$ for biotite hornblende granite and 57.14, 26.98, and $3.17 \%$ for coarse biotite granite. Table 4 presents the average grain of the samples. The results show that the average grain size vary from $0.94-0.99,0.65-0.68$ and $0.65-0.68 \mathrm{~mm}$ for feldspar granite, biotite hornblende granite and coarse biotite granite respectively.

Table 5 presents the silica content of the samples. The result shows that the silica content vary from 57.16-57.21, 82.5-82.72 and $76.04-76.12 \%$ for feldspar granite, biotite hornblende granite and coarse biotite granite respectively. Table 6 shows the porosity of the samples. The results revealed that porosity vary from $1.03-1.07,0.87-0.93$ and $0.72-0.74 \%$ for feldspar granite, biotite hornblende granite and coarse biotite granite respectively. Table 7 shows the packing density of the samples. The results show that the packing density vary from 92.18-94.53, 91.60-94.40 and 92.82-94.24\% for feldspar granite, biotite hornblende granite and coarse biotite granite respectively. 
Table 1: Mineral composition of Feldspar-Granite

\begin{tabular}{lllllll}
\hline Rock & Minerals & \multicolumn{5}{c}{ Percentage } \\
\cline { 3 - 6 } Code & & Location 1 & Location 2 & Location 3 & Location 4 & Location 5 \\
\hline IK01 & Biotite & 30.60 & 30.56 & 30.64 & 30.64 & 30.62 \\
& Quartz & 42.00 & 42.10 & 41.90 & 42.12 & 41.95 \\
& Plagioclase & 13.10 & 13.06 & 13.12 & 13.14 & 13.30 \\
& Opaque & 3.80 & 3.80 & 3.80 & 3.80 & 3.80 \\
& Orthoclase & 10.70 & 10.48 & 10.54 & 10.30 & 10.33 \\
Total & & 100.00 & 100.00 & 100.00 & 100.00 & 100.00 \\
\hline
\end{tabular}

Table 2: Mineral composition of Biotite Hornblende-Granite

\begin{tabular}{lllllll}
\hline Rock & Minerals & \multicolumn{5}{c}{ Percentage } \\
\cline { 3 - 7 } Code & & Location 1 & Location 2 & Location 3 & Location 4 & Location 5 \\
\hline IB02 & Microcline & 6.67 & 6.67 & 6.67 & 6.67 & 6.67 \\
& Hornblende & 8.89 & 8.89 & 8.89 & 8.89 & 8.89 \\
& Biotite & 17.78 & 17.80 & 17.75 & 17.81 & 17.82 \\
& Quartz & 51.11 & 51.09 & 51.18 & 51.14 & 51.07 \\
& Plagioclase & 6.66 & 6.66 & 6.64 & 6.66 & 6.66 \\
& Orthoclase & 2.22 & 8.89 & 8.87 & 8.83 & 8.89 \\
Total & & 100.00 & 100.00 & 100.00 & 100.00 & 100.00 \\
\hline & & \multicolumn{5}{c}{} \\
& & Table 3: Mineral composition of Coarse Biotite-Granite & \\
\hline Rock & Minerals & Location 1 & Location 2 & Location 3 & Location 4 & Location 5 \\
Code & & 12.70 & 12.70 & 12.70 & 12.70 & 12.70 \\
\hline DE03 & Hornblende & 26.98 & 27.00 & 27.01 & 27.01 & 26.96 \\
& Biotite & 57.14 & 57.10 & 57.12 & 57.09 & 57.16 \\
& Quartz & 3.17 & 3.20 & 3.17 & 3.20 & 3.18 \\
Total & Plagioclase & 100.00 & 100.00 & 100.00 & 100.00 & 100.00 \\
\hline
\end{tabular}

Table 4: Average grain size of selected rocks in Nigeria

\begin{tabular}{|c|c|c|c|c|c|}
\hline \multirow[t]{2}{*}{ Rock Name and Code } & \multicolumn{5}{|c|}{ Average grain size (mm) } \\
\hline & Location 1 & Location 2 & Location 3 & Location 4 & Location 5 \\
\hline $\begin{array}{l}\text { Feldspar-Granite } \\
\text { (IK01) }\end{array}$ & 0.94 & 0.99 & 0.96 & 0.99 & 0.95 \\
\hline $\begin{array}{l}\text { Biotite Hornblende- } \\
\text { Granite (IB02) }\end{array}$ & 0.67 & 0.66 & 0.69 & 0.69 & 0.65 \\
\hline $\begin{array}{l}\text { Coarse Biotite-Granite } \\
\text { (DE03) }\end{array}$ & 0.68 & 0.66 & 0.68 & 0.65 & 0.68 \\
\hline
\end{tabular}

Table 5: Silica content of selected rocks in Nigeria

\begin{tabular}{|c|c|c|c|c|c|}
\hline \multirow[t]{2}{*}{ Rock Name and Code } & \multicolumn{5}{|c|}{ Silica $(\%)$} \\
\hline & Location 1 & Location 2 & Location 3 & Location 4 & Location 5 \\
\hline $\begin{array}{l}\text { Feldspar-Granite } \\
\text { (IK01) }\end{array}$ & 57.17 & 57.19 & 57.16 & 57.21 & 57.17 \\
\hline $\begin{array}{l}\text { Biotite Hornblende- } \\
\text { Granite (IB02) }\end{array}$ & 82.64 & 82.60 & 82.72 & 82.7 & 82.50 \\
\hline $\begin{array}{l}\text { Coarse Biotite-Granite } \\
\text { (DE03) }\end{array}$ & 76.09 & 76.04 & 76.12 & 76.06 & 76.10 \\
\hline
\end{tabular}

Table 6: Porosity of selected rocks in Nigeria

\begin{tabular}{|c|c|c|c|c|c|}
\hline \multirow[t]{2}{*}{ Rock Name and Code } & \multicolumn{5}{|c|}{ Porosity (\%) } \\
\hline & Location 1 & Location 2 & Location 3 & Location 4 & Location 5 \\
\hline Feldspar-Granite (IK01) & 1.05 & 1.06 & 1.043 & 1.07 & 1.03 \\
\hline $\begin{array}{l}\text { Biotite Hornblende-Granite } \\
\text { (IB02) }\end{array}$ & 0.91 & 0.87 & 0.92 & 0.93 & 0.87 \\
\hline Coarse Biotite-Granite (DE03) & 0.73 & 0.72 & 0.74 & 0.72 & 0.74 \\
\hline
\end{tabular}


Table 7: Packing density of selected rocks in Nigeria

\begin{tabular}{llllll}
\hline Rock Name and Code & Packing Density (\%) & & & \\
\hline & Location 1 & Location 2 & Location 3 & Location 4 & Location 5 \\
\hline Feldspar-Granite (IK01) & 92.96 & 93.75 & 92.96 & 94.53 & 92.18 \\
Biotite Hornblende-Granite (IB02) & 91.95 & 91.95 & 93.00 & 94.40 & 91.60 \\
Coarse Biotite-Granite (DE03) & 92.88 & 93.52 & 92.82 & 94.24 & 92.82 \\
\hline
\end{tabular}

Table 8: Pentration rate of selected rocks in Nigeria

\begin{tabular}{|l|l|l|l|l|l|}
\hline Rock Name and Code & Penetration Rate (m/min) & \multicolumn{5}{l|}{} \\
\hline & Location 1 & Location 2 & Location 3 & Location 4 & Location 5 \\
\hline $\begin{array}{l}\text { Feldspar-Granite } \\
\text { (IK01) }\end{array}$ & 0.25 & 0.26 & 0.25 & 0.26 & 0.25 \\
\hline $\begin{array}{l}\text { Biotite Hornblende- } \\
\text { Granite (IB02) }\end{array}$ & 0.30 & 0.30 & 0.31 & 0.31 & 0.30 \\
\hline $\begin{array}{l}\text { Coarse Biotite-Granite } \\
\text { (DE03) }\end{array}$ & 0.30 & 0.29 & 0.30 & 0.29 & 0.30 \\
\hline
\end{tabular}

3.2 Penetration rate of the selected samples Penetration rate for all the samples vary from $0.25 \mathrm{~m} / \mathrm{min}$ for feldspar granite to $0.31 \mathrm{~m} / \mathrm{min}$ for Biotite hornblende-granite as presented in Table 8.

\subsection{The relationship between penetration rate and textural properties}

\subsubsection{Penetration Rate and Quartz Percentage}

The model coefficients for penetration rate and quartz content are presented in Table 9. It was observed that linear relationship exist between penetration rate and percentage of quartz for the selected rocks. The relationship is expressed in equation 4. The plot of penetration rate and regression standardized predicted value for quartz content shows that the model is valid having multiple coefficient of $\left(\mathrm{R}^{2}=0.689\right)$ as shown in Fig. 1. Also, the summary of the models presented in Table 10 confirms the validity of the model equation having multiple correlation coefficient of $\mathrm{R}^{2}=$ 0.830 .

$\mathrm{PR}=-211.163+0.657 \mathrm{QZ1}+0.937 \mathrm{QZ2}+2.380$ (4)

where,

$\mathrm{PR}=$ penetration rate,

QZ1, QZ2 and QZ3 are quartz content for feldspar granite, biotite hornblende granite and coarse biotite granite respectively.

Table 9: Coefficients of the model for penetration rate using quartz contents of the selected rocks

\begin{tabular}{|c|c|c|c|c|c|c|c|c|c|}
\hline \multirow{2}{*}{\multicolumn{2}{|c|}{ Model }} & \multicolumn{2}{|c|}{$\begin{array}{l}\text { Unstandardized } \\
\text { Coefficients }\end{array}$} & \multirow{2}{*}{$\begin{array}{c}\text { Standardize } \\
\mathrm{d} \\
\text { Coefficients } \\
\text { Beta } \\
\end{array}$} & \multirow{2}{*}{$\frac{\mathrm{t}}{\text { Zero-order }}$} & \multirow{2}{*}{$\begin{array}{c}\text { Sig. } \\
\text { Partial }\end{array}$} & \multicolumn{2}{|c|}{ Correlations } & \multirow[b]{2}{*}{ Std. Error } \\
\hline & & B & Std. Error & & & & Part & B & \\
\hline \multirow[t]{4}{*}{1} & (Constant) & -211.163 & 150.245 & & -1.405 & .394 & & & \\
\hline & QZ1 & .657 & .462 & 2.405 & 1.423 & .390 & .149 & .818 & .794 \\
\hline & QZ2 & .937 & .790 & 1.566 & 1.186 & .446 & -.174 & .765 & .662 \\
\hline & QZ3 & 2.380 & 1.651 & 2.633 & 1.442 & .386 & .229 & .822 & .804 \\
\hline
\end{tabular}

a Dependent Variable: PR

Table 10: Model summary for the variables of the selected rocks

\begin{tabular}{|c|c|c|c|c|c|c|c|c|c|}
\hline \multirow[t]{2}{*}{ Model } & \multirow{2}{*}{$\begin{array}{c}\mathrm{R} \\
\text { R Square } \\
\text { Change } \\
\end{array}$} & \multirow{2}{*}{$\begin{array}{l}\text { R Square } \\
\text { F Change } \\
\end{array}$} & \multirow{2}{*}{$\begin{array}{c}\begin{array}{c}\text { Adjusted R } \\
\text { Square }\end{array} \\
\\
\text { df1 } \\
\end{array}$} & \multirow{2}{*}{$\begin{array}{c}\text { Std. Error of } \\
\text { the Estimate } \\
\\
\mathrm{df} 2 \\
\end{array}$} & \multicolumn{5}{|c|}{ Change Statistics } \\
\hline & & & & & $\begin{array}{c}\text { Sig. F } \\
\text { Change }\end{array}$ & $\begin{array}{l}\text { R Square } \\
\text { Change }\end{array}$ & F Change & df1 & $\mathrm{df} 2$ \\
\hline 1 & $.830(\mathrm{a})$ & .689 & -.244 & .02887 & .689 & .738 & 3 & 1 & .671 \\
\hline 2 & $.842(a)$ & .709 & -.165 & .02794 & .709 & .811 & 3 & 1 & .652 \\
\hline 3 & $.825(\mathrm{a})$ & .681 & -.277 & .02925 & .681 & .711 & 3 & 1 & .679 \\
\hline 4 & .899 (a) & .809 & .234 & .02265 & .809 & 1.408 & 3 & 1 & .539 \\
\hline 5 & $.893(\mathrm{a})$ & .798 & .191 & .02329 & .798 & 1.314 & 3 & 1 & .553 \\
\hline
\end{tabular}




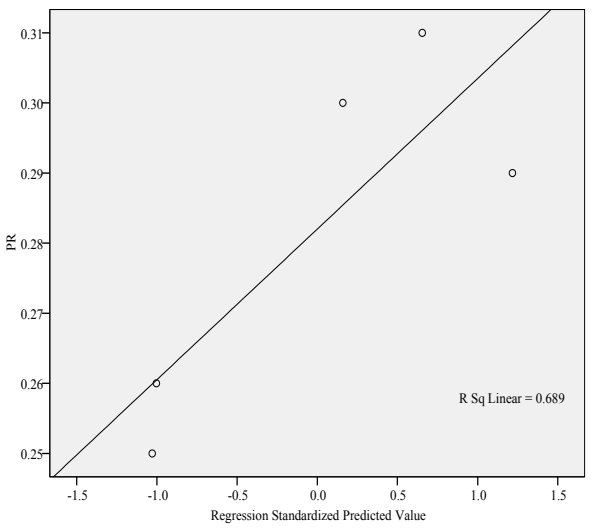

Fig. 1: Plot of penetration rate against regression standardized predicted value for quartz content

\subsubsection{Penetration Rate and Average Grain Size}

The model coefficients for penetration rate and average grain size are presented in Table 11. The model equation for prediction of penetration rate using average grain size of the selected rocks is expressed in equation 5 . The plot of penetration rate and regression standardized predicted value for average grain size shows that the model is valid having multiple coefficient of $\left(\mathrm{R}^{2}=0.709\right)$ as shown in Figure 2. Also, the summary of the models presented in Table 10 confirms the validity of the model equation having multiple correlation coefficient of $\mathrm{R}^{2}=0.842$, this shows that $84.2 \%$ of the variation in penetration rate could be attributed to average grain size of the selected rocks.

$\mathrm{PR}=3.52-1.004 \mathrm{AVG} 1-1.129 \mathrm{AVG} 2-$ 1.554AVG3

where,

$\mathrm{PR}=$ penetration rate,

AVG1, AVG2 and AVG3 are average grain size for feldspar granite, biotite hornblende granite and coarse biotite granite respectively.

Table 11: Coefficients of the model for penetration rate using average grain size of selected rocks

\begin{tabular}{|c|c|c|c|c|c|c|c|c|c|}
\hline \multicolumn{2}{|c|}{ Model } & \multicolumn{2}{|c|}{$\begin{array}{l}\text { Unstandardized } \\
\text { Coefficients }\end{array}$} & \multirow{2}{*}{$\begin{array}{c}\text { Standardized } \\
\text { Coefficients } \\
\text { Beta }\end{array}$} & \multirow{2}{*}{$\begin{array}{c}\mathrm{t} \\
\text { Zero- } \\
\text { order }\end{array}$} & \multirow{2}{*}{$\begin{array}{c}\text { Sig. } \\
\text { Partial }\end{array}$} & \multicolumn{3}{|c|}{ Correlations } \\
\hline & & B & $\begin{array}{l}\text { Std. } \\
\text { Error }\end{array}$ & & & & Part & $\mathrm{B}$ & $\begin{array}{l}\text { Std. } \\
\text { Error }\end{array}$ \\
\hline \multirow[t]{4}{*}{1} & (Constant) & 3.052 & 3.250 & & .939 & .520 & & & \\
\hline & AVG1 & -1.004 & 1.562 & -.893 & -.643 & .636 & -.319 & 54 & -.347 \\
\hline & AVG2 & -1.129 & .818 & -.780 & -1.380 & .399 & -.767 & $810^{-}$ & -.745 \\
\hline & AVG3 & -1.554 & 2.566 & -.849 & -.606 & .653 & .205 & $.518^{-}$ & -.327 \\
\hline
\end{tabular}

a Dependent Variable: PR

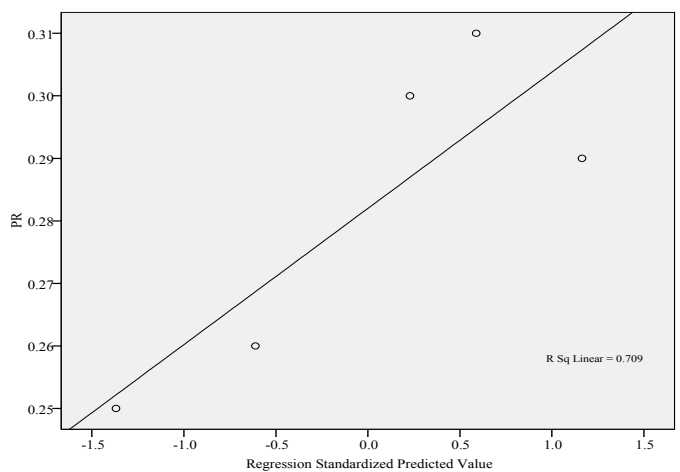

Fig. 2: Plot of penetration rate against regression standardized predicted value for average grain size

\subsubsection{Penetration Rate and Silica Content}

The model coefficients for penetration rate and silica content are presented in Table 12. The model equation for prediction of penetration rate using average grain size of the selected rocks is expressed in equation 6 . The plot of penetration rate and regression standardized predicted value for average grain size shows that the model is valid having multiple coefficient of $\left(\mathrm{R}^{2}=0.681\right)$ as shown in Figure 3. Also, the summary of the models presented in Table 10 confirms the validity of the model equation having multiple correlation coefficient of $\mathrm{R}^{2}=0.825$, this shows that $82.5 \%$ of the variation in penetration rate could be attributed silica content of the selected rocks.

$\mathrm{PR}=136.831-1.119 \mathrm{Si} 1-0.118 \mathrm{Si} 2-0.825 \mathrm{Si} 3$

where,

$\mathrm{PR}=$ penetration rate,

Si1, Si2 and Si3 are silica content for feldspar granite, biotite hornblende granite and coarse biotite granite respectively 
Table 12: Coefficients of the model for penetration rate silica contents of selected rocks

\begin{tabular}{|c|c|c|c|c|c|c|c|c|c|}
\hline \multicolumn{2}{|c|}{ Model } & \multicolumn{2}{|c|}{$\begin{array}{l}\text { Unstandardized } \\
\text { Coefficients }\end{array}$} & \multirow{2}{*}{$\begin{array}{l}\text { Standardized } \\
\text { Coefficients } \\
\text { Beta }\end{array}$} & \multirow{2}{*}{$\begin{array}{l}\text { t } \\
\text { Zero- } \\
\text { order }\end{array}$} & \multirow{2}{*}{$\begin{array}{l}\text { Sig. } \\
\text { Partial }\end{array}$} & \multicolumn{3}{|c|}{ Correlations } \\
\hline & & B & Std. Error & & & & Part & B & $\begin{array}{l}\text { Std. } \\
\text { Error }\end{array}$ \\
\hline \multirow[t]{4}{*}{1} & (Constant) & 136.831 & 135.873 & & 1.007 & .498 & & & \\
\hline & Sil & -1.119 & 1.411 & -.865 & -.794 & .573 & -.097 & -.622 & -.448 \\
\hline & $\mathrm{Si} 2$ & -.118 & .183 & -.401 & -.644 & .636 & -.629 & -.542 & -.364 \\
\hline & $\mathrm{Si} 3$ & -.825 & .873 & -1.018 & -.945 & .518 & -.339 & -.687 & -.534 \\
\hline
\end{tabular}

a Dependent Variable: PR

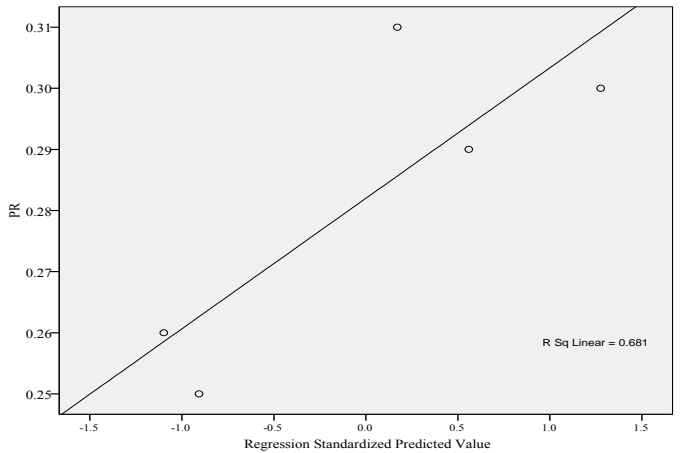

Fig. 3: Plot of penetration rate against regression standardized predicted value for silica content

\subsubsection{Penetration Rate and Porosity}

The model coefficients for penetration rate and porosity are presented in Table 13 . The model equation for prediction of penetration rate using average grain size of the selected rocks is expressed in equation 7. The plot of penetration rate and regression standardized predicted value for porosity shows that the model is valid having multiple coefficient of $\left(\mathrm{R}^{2}=0.809\right)$ as shown in Fig. 4. Also, the summary of the models presented in Table 10 confirms the validity of the model equation having multiple correlation coefficient of $\mathrm{R}^{2}=$ 0.899 , this shows that $89.9 \%$ of the variation in penetration rate could be attributed porosity of the selected rocks.

$\mathrm{PR}=16.620-8.159 \mathrm{n} 1+1.004 \mathrm{n} 2-11.876 \mathrm{n} 3$

where,

$\mathrm{PR}=$ penetration rate,

$\mathrm{n} 1, \mathrm{n} 2$ and $\mathrm{n} 3$ are porosity for feldspar granite, biotite hornblende granite and coarse biotite granite respectively.

Table 13: Table coefficients of the model for penetration rate using porosity of the selected rocks

\begin{tabular}{|c|c|c|c|c|c|c|c|c|c|}
\hline \multicolumn{2}{|c|}{ Model } & \multicolumn{2}{|c|}{$\begin{array}{l}\text { Unstandardized } \\
\text { Coefficients }\end{array}$} & \multirow{2}{*}{$\begin{array}{c}\text { Standardized } \\
\text { Coefficients } \\
\text { Beta } \\
\end{array}$} & \multirow{2}{*}{$\begin{array}{c}\mathrm{t} \\
\text { Zero- } \\
\text { order }\end{array}$} & \multirow{2}{*}{$\begin{array}{c}\text { Sig. } \\
\text { Partial }\end{array}$} & \multicolumn{3}{|c|}{ Correlations } \\
\hline & & $\mathrm{B}$ & Std. Error & & & & Part & B & Std. Error \\
\hline \multirow[t]{4}{*}{1} & (Constant) & 16.620 & 11.091 & & 1.498 & .375 & & & \\
\hline & $\mathrm{n} 1$ & -8.159 & 5.878 & -4.851 & -1.388 & .397 & -.123 & -.811 & -.607 \\
\hline & $\mathrm{n} 2$ & 1.004 & 1.212 & 1.097 & .829 & .559 & -.615 & .638 & .363 \\
\hline & n3 & -11.876 & 8.169 & -4.588 & -1.454 & .384 & -.193 & -.824 & -.636 \\
\hline
\end{tabular}

a Dependent Variable: PR

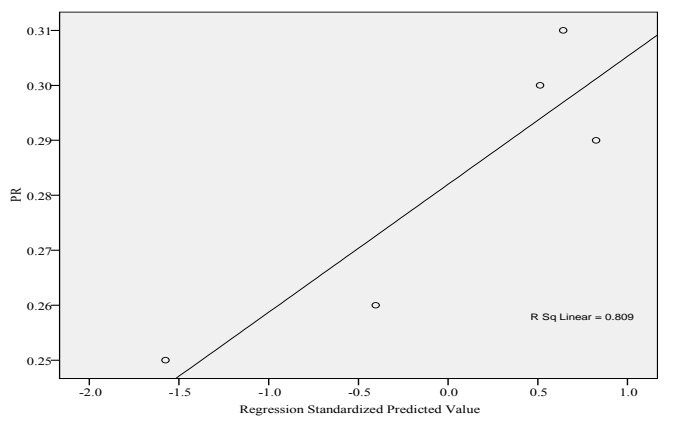

Fig. 4: Plot of penetration rate against regression standardized predicted value for porosity

\subsubsection{Penetration Rate and Packing Density}

The model coefficients for penetration rate and packing density are presented in Table 14. The model equation for prediction of penetration rate using average grain size of the selected rocks is expressed in equation 8 . The plot of penetration rate and regression standardized predicted value for packing density shows that the model is valid having multiple coefficient of $\left(\mathrm{R}^{2}=0.798\right)$ as shown in Fig. 5. Also, the summary of the models presented in Table 10 confirms the validity of the model equation having multiple correlation coefficient of $\mathrm{R}^{2}=$ 0.893 , this shows that $89.9 \%$ of the variation in 
penetration rate could be attributed packing density of the selected rocks.

$\mathrm{PR}=0.733+0.013 \mathrm{PD} 1-0.030 \mathrm{PD} 2+0.012 \mathrm{PD} 3$

where,

$\mathrm{PR}=$ penetration rate,
PD1, PD2 and PD3 are packing density for feldspar granite, biotite hornblende granite and coarse biotite granite respectively.

Table 14: Coefficients of the model for penetration rate using packing density

\begin{tabular}{|c|c|c|c|c|c|c|c|c|c|}
\hline \multicolumn{2}{|c|}{ Model } & \multicolumn{2}{|c|}{$\begin{array}{l}\text { Unstandardized } \\
\text { Coefficients }\end{array}$} & \multirow{2}{*}{$\begin{array}{c}\text { Standardized } \\
\text { Coefficients } \\
\text { Beta }\end{array}$} & \multirow{2}{*}{$\begin{array}{c}\mathrm{t} \\
\text { Zero-order } \\
\end{array}$} & \multirow{2}{*}{$\begin{array}{c}\text { Sig. } \\
\text { Partial } \\
\end{array}$} & \multicolumn{3}{|c|}{ Correlations } \\
\hline & & B & Std. Error & & & & Part & B & Std. Error \\
\hline \multirow[t]{4}{*}{1} & (Constant) & .733 & 2.127 & & .345 & .789 & & & \\
\hline & PD1 & .013 & .039 & .457 & .334 & .795 & -.288 & .317 & .150 \\
\hline & PD2 & -.030 & .016 & -1.316 & -1.878 & .311 & -.762 & -.883 & -.845 \\
\hline & PD3 & .012 & .054 & .278 & .213 & .866 & -.262 & .208 & .096 \\
\hline
\end{tabular}

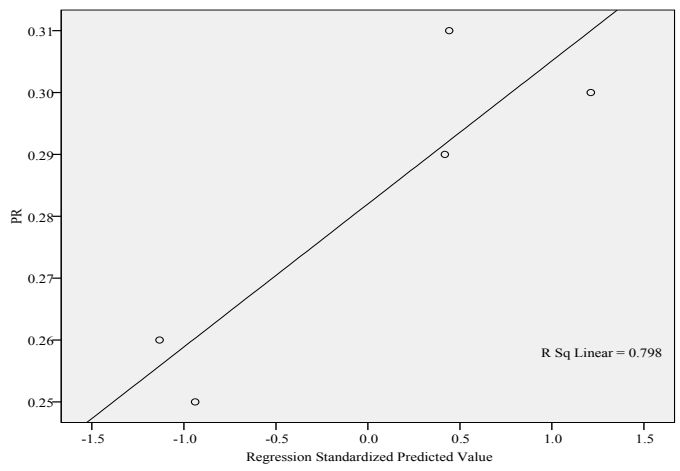

Fig. 5: Plot of penetration rate against regression standardized predicted value for packing density

\section{Conclusion}

Investigating the relationship between penetration rate and textural properties of rocks are essential to understand the behaviour of rock under mechanical loading. The penetration rate is an important variable to be able to project time to drill in mines or quarry. Among the textural properties selected for this study viz., quartz proportion, silica content, average grain size, porosity and packing density. All these properties were found to have strong relationship with penetration rate. It could be concluded that rock drill penetration are different because of variation in the textural characteristics of these rocks.

\section{References}

[1] Bilgin, Demircin, N. Copur, M.A. H., Balci, C. Tuncdemir, $\mathrm{H}$. and Akcin, N. Dominant rock properties affecting the performance of conical picks and comparison of some experimental and theoretical results. International Journal of Rock Mechanics Science, Vol. 43, 2006. pp. 139-156
[2] William, H. Turner, F.J. and Gilber, C.M.(1982) .Petrograhy, W.H Freeman Company Publisher, San Francisco, U.S.A. 369p

[3] Erosy, A. and Waller, M.D. (1995). Textural characteristics of rocks. Engineering Geology, Elsevier, Amsterdam, The Nertherland, pp. 123136

[4] Ulusay, R Tureli, K.and Ider, M.H.(1994). Prediction of engineering properties of a selected litharenite sandstone from its petrographic characteristics using correlation and multivariate statistical techniques, Engineering Geology, 37, pp. $135-157$

[5] Tug rul, A. and Zarif, I.H. (1999). Correlation of mineralogical and textural charateristics with engineering properties of selected granitic rock from Turkey, Vol. 51, Issue 4, pp. 303-317

[6] Bieniawski, Z.T. (1967). Mechanism of brittle fracture in rock. International Journal of Rock Mechanics Science, 4 pp. 395-430

[7] Scoble, M. J. Peak, J. and Handrick, C. (1989). Correlation of between Rotary Drill Performance Parameters and Borehole Geophysical Logging, Mining Science and Technology, pp 301-312.

[8] Gaterlier, N. Pellet, F. and Loret, B. (2002). Mechanical damage of an anisotropic porous rock in cyclic triaxial test, International Journal of Rock Mechanics Science, 43, pp. 335-354.

[9] Beste, U. Lundvall, A. and Jacobson, S. (2004). Micro-scratch evaluation of rock types- a means to comprehend rock drill wear. International journal of Rock Mechanics Science, Vol. 37, Issue 2, pp. 203-210.

[10] Kahraman,, S. Bilgin, C. and Feridunoglu, C. (2003). Dominant Rock Properties Affecting Penetration Rate of Percussive Drills, International Journal of Rock Mechanics and Mining Science, Vol 40 No. 2, pp 711 -723. 
[11] Shahram, M. (2007). Measurement while Drilling System in Aitik Mine, M.Eng Thesis School of Applied Geosciences and Mining, Lulea University of Technology, Sweden, pp 1-36.

[12] ASTM, (2003). Standard Test Methods for Chemical Analysis of Hydraulic Cement, Annual Book of ASTM Standards, Vol.04.01. C114 - 03.

[13] ISRM, (1989). Rock characterization testing and monitoring: International Society for Rock
Mechanics Commission. Ed. E.T. Brown, Pergamon press, 1989, pp 75-105.

[14] Kahn, J.S. (1956). The analysis and distribution of the properties of packing density and size sediments, Journal of Geology, 64(1956), pp 385395 